\title{
Making headway in climate policy mainstreaming and ecosystem-based adaptation: two pioneering countries, different pathways, one goal
}

\author{
Christine Wamsler ${ }^{1} \cdot{\text { Stephan } \text { Pauleit }^{2}}^{2}$
}

Received: 9 October 2015 / Accepted: 19 March 2016/Published online: 16 April 2016

(C) The Author(s) 2016. This article is published with open access at Springerlink.com

\begin{abstract}
Ecosystem-based adaptation (i.e. the use of ecosystem services to adapt to climate change) and its mainstreaming into municipal planning to foster sustainable transformation is receiving increasing interest from both academic and governmental bodies. However, little is known about the pathways for its systematic implementation, or the extent to which it is already mainstreamed in municipal planning practice. This article reports on a study in which local pathways to sustainably mainstream ecosystem-based adaptation were compared in 12 municipalities in Germany and Sweden. The results show that while progress is seemingly similar in the two countries, there are noticeable differences regarding the local triggers, the importance given to particular mainstreaming strategies and their link to climate policy integration. Ecosystem-based approaches to climate change adaptation are not labelled or systematised in either country. In addition, the mainstreaming of ecosystem-based adaptation is enabled through municipalities' level of experience in mainstreaming other issues. In Sweden, the ecosystem service concept drives adaptation mainstreaming, which is often disconnected from the integration of climate mitigation policy. In contrast, German structures and planning processes established for climate change mitigation are paving the way. We conclude that systematic adaptation mainstreaming and its potential linkages and disconnects with climate mitigation policy integration require more explicit consideration, both in research and practice. We call for more research on the role of inclusive (as opposed to fragmented) climate policy integration to assure sustainable planning and transformation.
\end{abstract}

Christine Wamsler

christine.wamsler@lucsus.lu.se

1 Lund University Centre for Sustainability Studies (LUCSUS) and Centre for Societal Resilience, Lund, Sweden

2 Strategic Landscape Planning and Management, Technical University of Munich (TUM), Munich, Germany 


\section{Introduction}

The concept of ecosystem-based adaptation is advocated at international, national and local levels, and its potential to foster sustainable municipal development and transformation is receiving increasing interest from academic and governmental bodies alike (EC 2015; Jones et al. 2012; IPCC 2014; Wilkinson et al. 2013; Wu 2014). However, little is known about the pathways for its systematic implementation (Andrade et al. 2011; IPCC 2014; Sitas et al. 2014; Vignola et al. 2009), and it remains unclear to what extent the concept is already being mainstreamed in municipal planning practice (Sitas et al. 2014; Turnpenny et al. 2014) ${ }^{1}$.

Ecosystem-based adaptation can be defined as the use of ecosystem services and biodiversity as part of an overall adaptation strategy to help people to adapt to the adverse effects of climate change (CBD 2009). This relatively new concept aims to increase humans' resilience to climate change using both natural and managed ecosystems (Andrade et al. 2011), with managed ecosystems typically located in cities. Ecosystem-based adaptation is increasingly considered as an alternative or complement to traditional, engineering-based approaches, which has the potential to be more costeffective and generate multiple co-benefits, including climate change mitigation (Jones et al. 2012; Munang et al. 2013). The concept of nature-based solutions for climate change adaptation supports and builds on the ecosystem services concept, and can even be used synonymously with ecosystembased adaptation (EC 2015; Naumann et al. 2014). Both concepts are embedded in the theory and practice of climate change adaptation and ecosystem services (Chong 2014; Uy and Shaw 2012). The need to mainstream ecosystem-based adaptation into municipal planning is widely advocated (Daily and Matson 2009; Daily et al. 2009; Gaffin et al. 2012; Ojea 2015; Pasquini and Cowling 2014). The concept of climate adaptation mainstreaming has two main roots. First, it has developed from risk reduction mainstreaming, which has been strongly advocated since the Word Conference on Disaster Risk Reduction in 2005 (UNISDR 2005) and builds on experiences from mainstreaming other cross-cutting issues, such as HIV/Aids and gender (Holden 2004; Mazey 2002). Second, climate adaptation mainstreaming originates from environmental policy integration $(\mathrm{EPI})^{2}$ for sustainable development (United Nations 1987; Lenschow 2002; Van Asselt et al. 2015), and more specifically climate policy integration or mainstreaming, which has been promoted since 1997 (Collier 1997). ${ }^{3}$ Broadly defined, climate policy integration/mainstreaming refers to the inclusion of climate considerations in sector policy and practice (Berkhout et al. 2015; Mullally and Dunphy 2015). Although often couched in technical language, mainstreaming is motivated by the need to change the dominant paradigm at multiple levels of governance (Wamsler 2014; La Trobe and Davis 2005; Picciotto 2002, Persson 2004). It changes the rules of the game and challenges ideas, attitudes, or activities that are considered mainstream or normal (Picciotto 2002). In turn, this is related to the concepts of sustainable transformation and transformative adaptation (IPCC 2012, 2014; Pelling et al. 2014; Westley et al. 2011), where the latter is recognized for its potential to address root causes of risk and failed approaches to sustainable development (Revi et al. 2014).

The themes that emerge from the literature on mainstreaming climate change adaptation and other cross-cutting issues (e.g., environmental policy, risk reduction, HIV/Aids, gender) can be

\footnotetext{
${ }^{1}$ Exceptions are for instance Pasquini and Cowling (2014) who focus on Western Cape, South Africa.

${ }^{2}$ EPI is in some contexts also denoted environmental mainstreaming (Dalal-Clayton and Bass 2009).

${ }^{3}$ Note that originally only integrating the objective to reduce greenhouse gas emissions into other sectoral policies was referred to as climate policy integration/mainstreaming, but this focus has been gradually broadened to also include adaptation considerations since around 2012 (IPCC 2012; Mullally and Dunphy 2015; CasadoAsenio and Steurer 2012; Van Asselt et al. 2015).
} 
divided into seven strategic activities (cf., Benson et al. 2007; Eggenberger and Partidario 2000; Lafferty 2002; Holden 2004; Jacob and Volkery 2004; Jordan and Lenschow 2010; La Trobe and Davis 2005; Nunan et al. 2012; Swart and Raes 2007). The mainstreaming framework presented in Table 1 encompasses and consolidates these strategies, including normative, operational and strategic (i.e., organisational and procedural) factors at different policy making stages (cf. Persson 2004; Collier 1994). The different mainstreaming strategies are comprehensive and complementary in the sense that they involve both the type and scale of integration, link direct (dedicated) and

Table 1 Mainstreaming framework: Overview of complementary mainstreaming strategies (cf. Fig. 2)

Strategies (and levels) of mainstreaming

(1) Add-on mainstreaming

(2) Programmatic mainstreaming

(3) Managerial mainstreaming

$(4,6)$ Intra- and interorganizational mainstreaming

(5) Regulatory mainstreaming**

(7) Directed mainstreaming***
The establishment of specific on-the-ground projects or programmes that are not an integral part of the implementing body's sector work but directly target adaptation* or related aspects.

The modification of the implementing body's sector work by integrating aspects related to adaptation* into on-the-ground operations, projects or programmes.

The modification of managerial and working structures, including internal formal and informal norms and job descriptions, the configuration of sections or departments, as well as personnel and financial assets, to better address and institutionalize aspects related to adaptation*.

The promotion of collaboration and networking with other departments, individual sections or stakeholders (i.e., other governmental and non-governmental organizations, educational and research bodies and the general public) to generate shared understanding and knowledge, develop competence and steer collective issues of adaptation*.

The modification of formal and informal planning procedures, including planning strategies and frameworks, regulations, policies and legislation, and related instruments that lead to the integration of adaptation*.

Higher level support to redirect the focus to aspects related to mainstreaming adaptation* by e.g., providing topic-specific funding, promoting new projects, supporting staff education, or directing responsibilities.

\footnotetext{
* The mainstreaming framework can be applied to overall adaptation, or specific aspects of it (e.g. ecosystembased approaches), as well as to other cross-cutting topics such as climate change mitigation. If applied to adaptation, all strategies require a comprehensive approach for climatic risk reduction (including measures of hazard reduction and avoidance, vulnerability reduction, preparedness for response and preparedness for recovery [Wamsler and Brink 2014]). Further note that the framework can be applied to single municipal departments or other implementing bodies at all levels. Their collaboration and networking with other stakeholders (strategy 6) is crucial since governance and problem scales are often mismatched. Finally, internal mainstreaming was not explicitly included in this study. It can be seen as an integral component of managerial mainstreaming aimed at addressing the implementing body's own challenges, e.g., risks to premises and assets, to ensure that adaptation work can continue even during adverse events.

** The combination of strategies 3, 5 and 6 can also be denoted as organisational mainstreaming.

*** Directed mainstreaming can be seen as an integral component of all of the other strategies as it concerns how related changes come about (e.g., top-down versus bottom-up) (cf. Fig. 2).
}

Sources: Adapted from Wamsler (2014, 2015a, b) and Wamsler et al. (2014). 
indirect approaches to adaptation (cf. Uittenbroek et al. 2013) and are all required for achieving sustainable transformation (Wamsler 2014).

On this basis, this study examines and compares local pathways to sustainably mainstream ecosystem-based adaptation into municipal planning and discusses their linkages or discrepancies with local processes for climate policy integration/mainstreaming. Germany and Sweden were selected for a comparative case study.

\section{Methods}

A critical comparative case study approach was applied to examine the key characteristics (differences and similarities) of mainstreaming ecosystem-based adaptation into municipal planning. Germany and Sweden were selected because ecosystem-based approaches are a declared goal of their respective national governments (BfN 2012; SOU 2007, 2013; Ministry of the Environment 2013). In addition, both countries are pioneers in environmental and climate-change governance (DC 2014; Jost and Jacob 2004; Hertin and Berkhout 2001; Jordan and Lenschow 2000) and top the Global Green Economy Index (DC 2014).

A total of 12 municipalities in southern Germany (Bavaria) and southern Sweden (Scania) were selected. Eight are German municipalities: Munich, Nuremberg, Regensburg, Würzburg, Landshut, Passau, Deggendorf and Freising, and four are in Sweden: Malmö, Helsingborg, Kristianstad and Lomma (Fig. 1). As this was an exploratory study, the municipalities were selected using purposive sampling, based on two criteria: (i) their risk exposure to heat and flood (DWD 2014; Länsstyrelserna 2012; SMHI 2011), and (ii) their proactive engagement in climate risk-related research and projects. ${ }^{4}$

Data were collected in both countries during 2014-2015 using face-to-face interviews, a survey of municipal officials working in departments responsible for spatial or environmental planning, and a literature review. A total of thirty-six in-depth interviews were carried out. The interviewees and survey participants were selected through purposive sampling, based on their field of activity within the municipality, and their participation in adaptation and ecosystem-related activities. The literature review extended the data by providing contextual information on the selected countries and municipalities, their activities, planning structures and instruments (organisational charts, job descriptions, development and climate strategies, regional and sectoral plans, comprehensive and detailed plans, etc.).

Based on the mainstreaming framework (Table 1), data were analysed using a combination of literal reading, Grounded Theory (Glaser and Strauss 1967; Corbin and Strauss 1990) and Systems Theory (Bateson 1979; von Bertalanffy 1950). Glaser and Strauss acknowledge that it is possible to discover and work with prior/tentative theoretical frameworks, which they also

\footnotetext{
${ }^{4}$ This led to the identification of 12 municipalities (Fig. 1). Their proactive engagement includes participation in Germany in the ExWoSt project (2009-2013) of the German Federal Ministry for the Environment, Nature Conservation and Nuclear Safety (BMUB); the Centre for Urban Ecology and Climate Adaptation ZSK 2013-16 financed by the Bavarian Ministry for Environment and Consumer Protection (StMUV); the Klimmzug project (2008-2014) financed by the German Federal Ministry of Education and Research and activities related to the European floods in 2013. In the Swedish context, it includes two regional cooperation and research circles ("Planning Under Increased Uncertainty" and "Ecosystem Services Planning") and two major research projects ("Ecosystem Services as a Tool for Climate Change Adaptations in Coastal Municipalities" and "Sustainable Urban Transformation for Climate Change Adaptation”).
} 

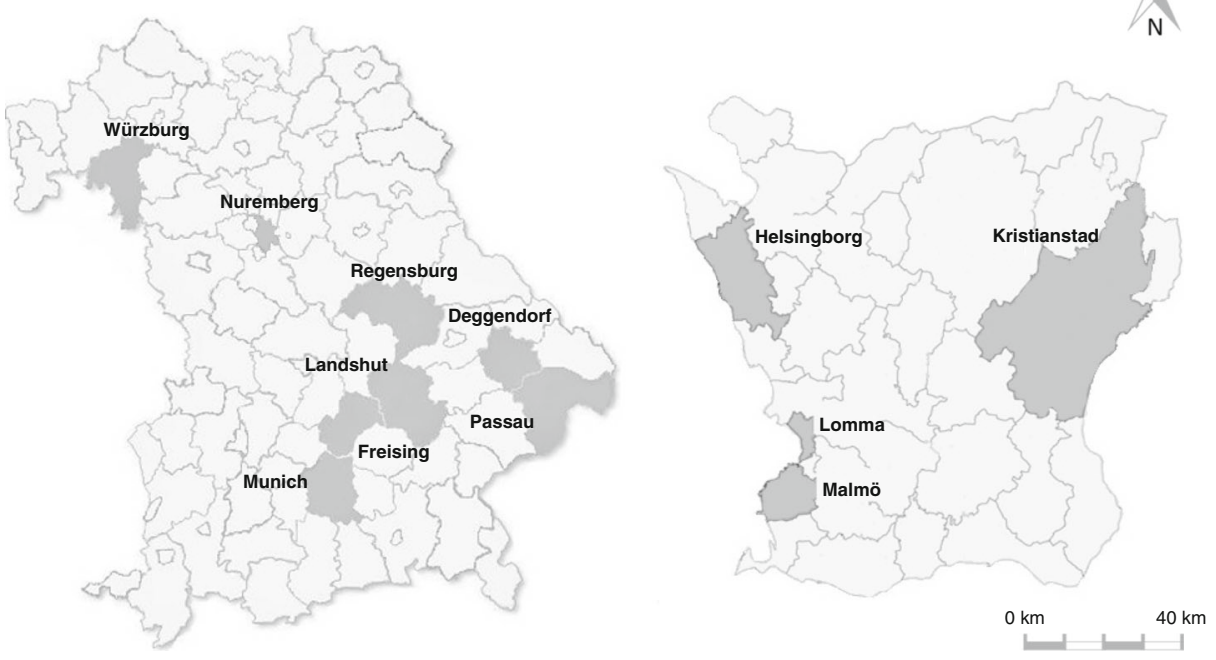

Fig. 1 Case study areas in Germany and Sweden (Bavaria and Scania region)

call 'substantive theory' (as opposed to 'formal theory') (Glaser and Strauss 1980; Layder 2005:20). ${ }^{5}$ Preliminary outcomes included country-specific studies and an operational framework for adaptation mainstreaming that has been tested in selected municipalities in Germany and Sweden (Wamsler 2015a, b; Wamsler et al. 2014).

Finally, during four workshops and group discussions with municipal staff and interviews with key informants (from Munich, Würzburg, Kristianstad and Helsingborg) the preliminary outcomes were further assessed, additional data were collected and compared and the related outcomes were discussed (e.g., identified patterns and differences, such as the importance of contextual factors and municipalities' prior policy integration experience, cf. Table 2). ${ }^{6}$ In addition, the survey data was re-assessed to look further into certain aspects (especially the interlinkages and discrepancies between climate mitigation and climate adaptation policy integration). The result of this follow-up data collection and analysis is presented in the following sections.

\section{Results}

Our analysis provides insights into the potential pathways for sustainably mainstreaming ecosystem-based adaptation into municipal planning and how they are linked to processes

\footnotetext{
${ }^{5}$ Consistent with Grounded Theory, a combination of open coding, axial coding and selective coding was applied to the empirical data (Strauss and Corbin 1998; Glaser and Strauss 1980). Based on the mainstreaming framework, patterns were identified within the established categories through a comparison of the different empirical data during the analysis process, which included literal reading. During axial coding, the commonly-used linear paradigm model was expanded by a broader (non-linear) systems analysis approach. Note that the analysis of local impacts of ecosystem-based adaptation (strategies and measures) is outside the scope of this study.

${ }^{6}$ Key informants, who were the most information-rich (i.e. knowledgeable and varied) informants, were municipal staff members who had particular knowledge and understanding of ecosystem-based adaptation due to related responsibilities and/or engagement (e.g., adaptation managers).
} 


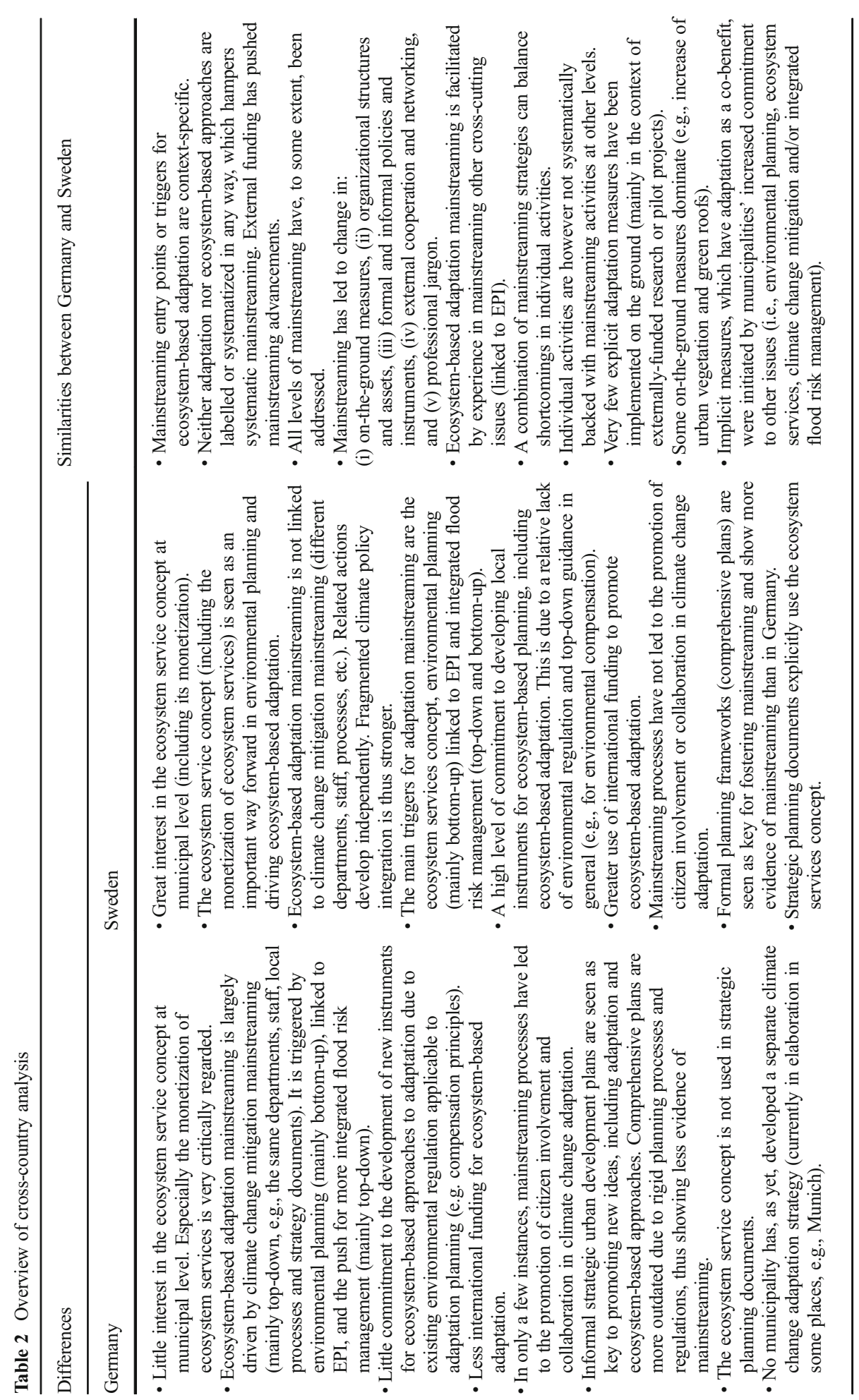




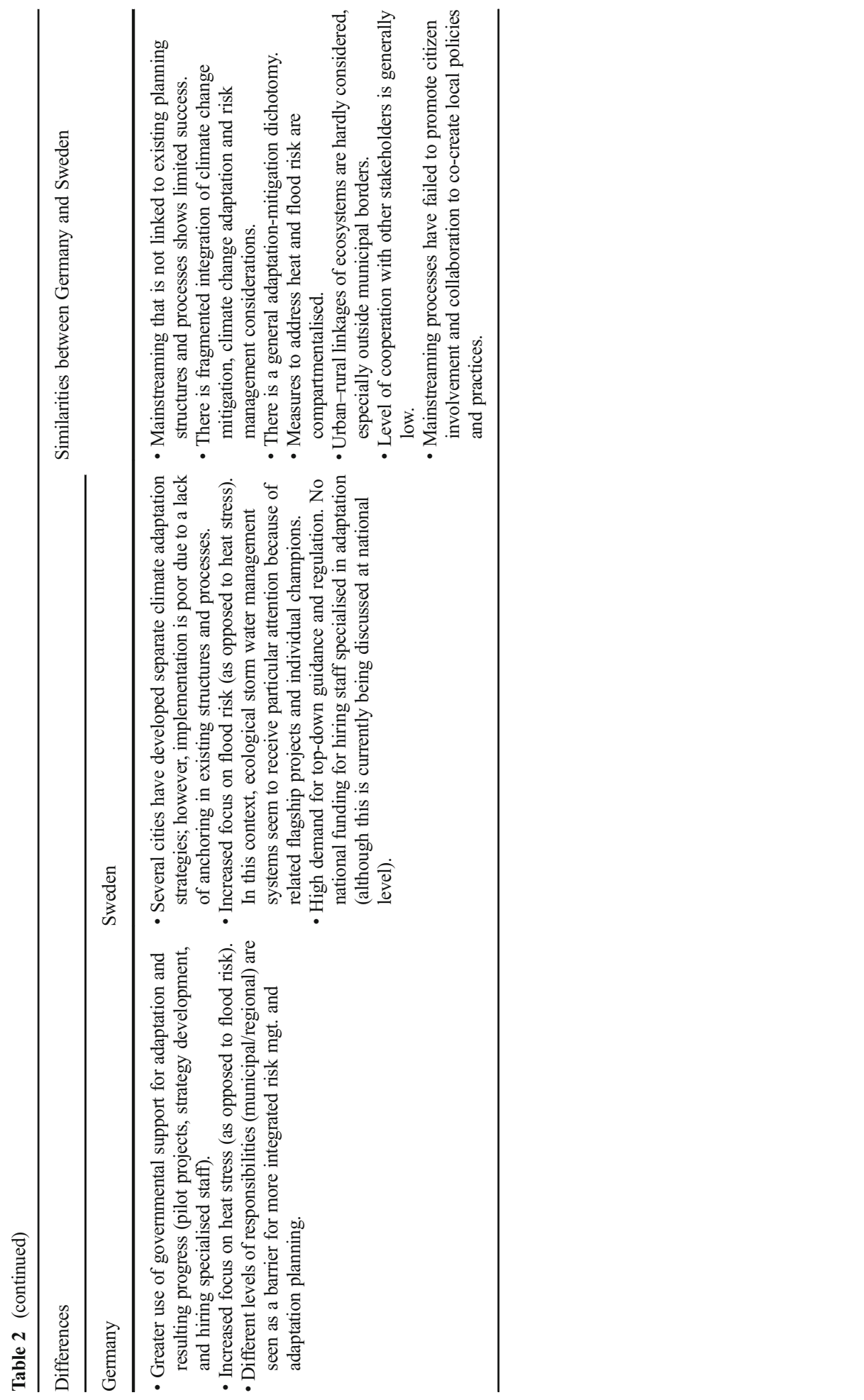


for climate policy integration/mainstreaming. The differences and similarities identified in the German and Swedish contexts are elaborated in the following sections (3.1 and 3.2). They are summarised in Table 2 and related to the mainstreaming strategies presented in Table 1.

\subsection{Differences}

The results of the study show that mainstreaming triggers or entry points for ecosystem-based adaptation are appreciably different and context-specific. On the one hand, in Sweden the ecosystem service concept promoted at national level was rapidly adopted by municipal officials, and has become a key driver for nature-based planning approaches at local level. In 2013, the Government produced a report called "Making the value of ecosystem services visible", which set the goal of ensuring that, by 2018, "the importance of biodiversity and the value of ecosystem services are to be generally known and integrated into economic positions, political considerations and other decisions in society" (Ministry of the Environment 2013: 3; SOU 2013). This policy (which can be considered as part of the country's EPI strategy) provided long-hoped-for support for municipal actions, such as the development of planning tools designed to support the provision of compensation for environmental impacts (in Malmö, Helsingborg, Lomma and Kristianstad; strategy 3). A lack of (and a call by municipalities for more) environmental regulation and top-down guidance for climate change adaptation in Sweden are important factors driving this process. In this context, the process of adaptation mainstreaming can be seen as a by-product of EPI, which is, however, not linked to local integration efforts concerned with climate change mitigation.

In Germany, on the other hand, climate change mitigation is paving the way for climate change adaptation, including ecosystem-based approaches. In fact, the mainstreaming of ecosystem-based adaptation has directly evolved out of the policies, organisational structures, personnel and financial assets, planning processes, instruments and measures that were originally developed for climate mitigation policy integration (strategies 1-6). For instance, in most German cities climate change mitigation managers, recruited in increasing numbers since 2013 (strategy 3) and co-financed through national funds (strategy 7), have gradually been given responsibility for climate change adaptation. Similar support is not available to Swedish municipalities. However, this situation may soon change as a report commissioned by the Swedish Government recommends creating a national fund for the employment of municipal climate change adaptation managers (Andersson et al. 2015).

Unlike Sweden, progress in Germany is completely unrelated to the concept of ecosystem services, and local officials show no interest in future application of the concept. It is not perceived to be of real benefit. This may be due to the existence of other well-established concepts such as landscape or ecological functions (cf. Albert et al. 2012, 2014), and a related extensive body of regulation and instruments for EPI (e.g., for environmental impact mitigation and compensation). Consequently, in Germany there is also comparatively little involvement in (or call for increased) regulatory mainstreaming for ecosystem-based adaptation at municipal and higher levels.

In addition, compared to the German context, Swedish officials are more active in attracting international funding for adaptation in general and ecosystem-based adaptation in particular (strategies 3,6). However, temporary support may lead to limited advancements (see Section 3.2).

Furthermore, there are very few examples where mainstreaming has led to the promotion of collaborative arrangements (between cities and citizens) to co-create local policies and 


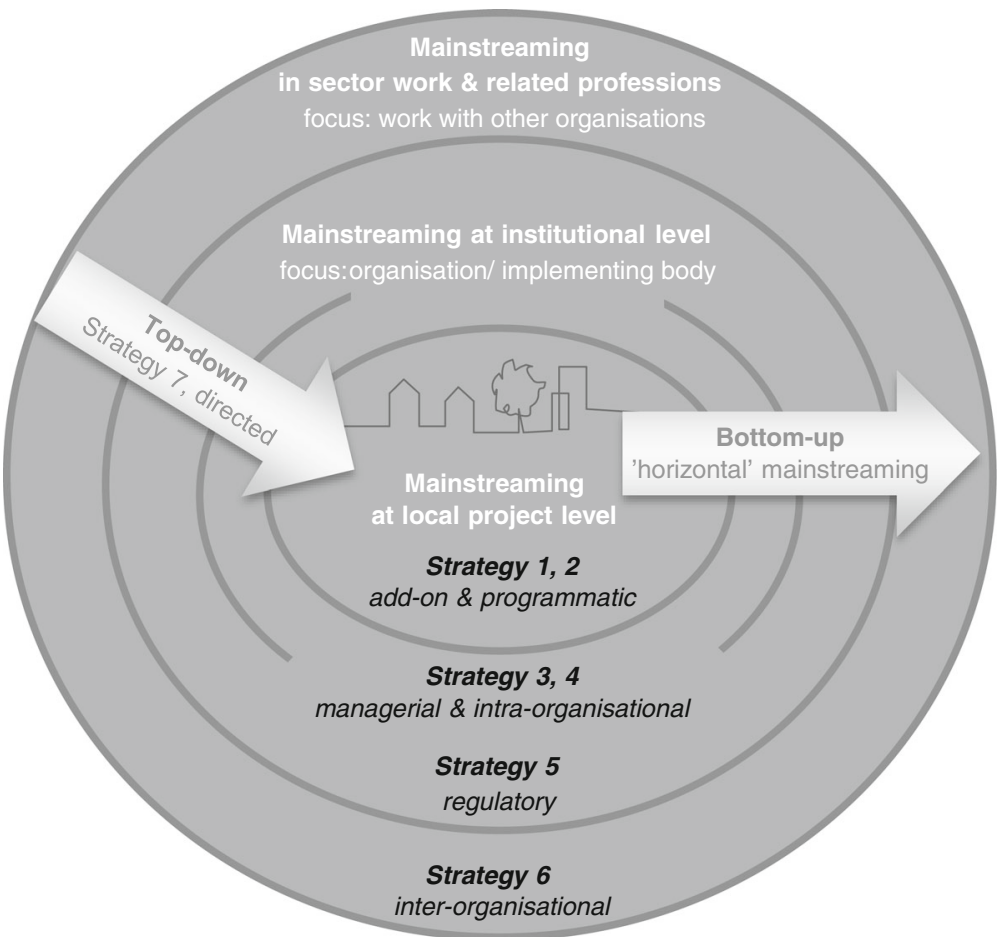

Fig. 2 Mainstreaming framework: Strategies and levels of mainstreaming. Note that the mainstreaming framework can be applied to organisations at all levels. The different mainstreaming strategies are complementary. (cf. Table 1). Source: Adapted from Wamsler (2014). Managerial mainstreaming includes here internal mainstreaming activities; inter-organisational mainstreaming comprises educational mainstreaming activities

practices while the few exceptions tend to come from Germany (strategy 6, cf. Section 3.1). Examples are financial incentives, citizen competitions and cooperation aimed at reducing soil sealing and increasing greening on private lots, and appointing local 'godparents' to support the maintenance and flood control of local stretches of water. The low level of citizen participation in Sweden was also confirmed by a recent self-assessment of local processes for sustainable development, where citizen participation was ranked last in many municipalities, such as Helsingborg (ICLEI Europe 2015).

Another difference is that formal planning frameworks (comprehensive plans) show more evidence of adaptation mainstreaming in Sweden (strategy 5). This relates to the fact that, overall, these frameworks are more recent and thus reflect new ideas and developments. In contrast, informal planning is seen as key to promoting ecosystem-based adaptation in Germany due to the highly regulated and time-consuming formal planning processes (strategy 5$)^{7}$

Finally, German municipalities tend to focus on ecosystem-based adaptation to heat stress rather than floods, while the reverse is true in Sweden, partially explained by geographical differences. However, in Sweden "new" emerging hazards (such as heat) receive less attention,

\footnotetext{
${ }^{7}$ In those German cities where previous mainstreaming experience was relatively low, the development of informal (strategic urban development) plans were an important trigger for mainstreaming.
} 
despite the fact that heatwaves have resulted in higher national death rates than floods (Johansson and Mobjörk 2009).

\subsection{Similarities}

The results show that in both countries, ecosystem-based approaches to adaptation are receiving increasing attention and all levels of mainstreaming have to some extent been addressed in practice (Table 1, Fig. 2). This has led to patterns of change in normative (e.g., political leadership, overall policy frameworks, policy-making culture), organisational (e.g., integrated departments, new coordination mechanisms) and procedural factors (e.g., climate assessment procedures). More specifically, in both countries it has led to changes in on-theground measures (Table 1, strategies 1,2), municipalities' organisational structures and assets (Table 1, strategies 3, 4), formal and informal policies and instruments (Table 1, strategy 5), external cooperation and networking (Table 1, strategy 6), and related professional jargon.

In both countries, a high level of involvement in some mainstreaming activities compensates, to some extent, for a lack of progress in other areas. A lack of (national or municipal) legislation and political support (Table 1, strategy 7) is, for instance, compensated by dedicated civil servants working at local level who streamline and regulate activities within their sphere of influence, submit applications for external (international or national and regional) adaptation funding, and push to join adaptation-related networks (e.g., Majors Adapt in Germany ${ }^{8}$ and ICLEI - Local Governments for Sustainability in Sweden). Strategic engagement in backing individual activities with other activities at all levels of mainstreaming is, however, absent.

In fact, in both countries the mainstreaming of ecosystem-based adaptation can be mainly seen as 'indirect integration' (Lenschow 1999), i.e., a rather unplanned process, which is still in its infancy ${ }^{9}$, and very few explicit (adaptation-targeted) on-the-ground measures have been implemented (strategies 1-2). Ecosystem-based adaptation involves different types of on-theground measures, including the creation, conservation, restoration and management of ecosystems provided by green and blue infrastructure (Colls et al. 2009; IPCC 2014). More specifically, measures can include re-naturalizing river systems; maintaining or enhancing the quantity and quality of urban green; promoting the use of vegetation adapted to local conditions/climate; and ensuring ventilation from cooler areas outside the city through waterway and green areas (Geneletti and Zardo 2016; EEA 2012; Wamsler et al. 2016). Concrete measures thus involve a wide range of ecosystem management activities consisting of bluegreen infrastructure components (such as parks, gardens, trees in streets, permeable surfaces, green roofs and walls, urban wetlands, watercourses, ponds and lakes) that can have climate risk reduction both as an intended (explicit) or unintended (implicit) aim or co-benefit (Wamsler et al. 2016).

The results show that some measures dominate (i.e., maintenance, development or increase of urban vegetation in streets, parks, green corridors and other public or private areas and green roofs), whilst ecological storm water management systems seem to receive more attention in Swedish municipalities. The latter is linked to individual champions and related flagship projects (such as Augustenborg in Malmö).

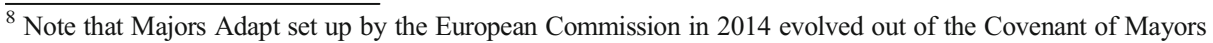
initiative on climate change mitigation. The described similarity thus also links to the identified differences between Germany and Sweden regarding the adaptation-mitigation link discussed in Section 3.1.

${ }^{9}$ This statement is based on both the interviewees' own statements/self-assessments and the data analysis described in Section 2.
} 
In addition, ecosystem-based approaches to climate change adaptation are so far not labelled or systematised in any way in Germany and Sweden, illustrated by the following statement from a German official: "We deal with the issue of adaptation in a very broad or general sense, and the differentiation between constructive [engineering-focused] and other types of adaptation measures is, in practice, not yet a topic. We are not there yet. [...] We still have a 'smörgåsbord' of ideas; we still don't have an overview. This will come with further conceptualization. Then we will perhaps start to systematise, and then perhaps also see where we have deficits, where we could advance adaptation in different ways." This also applies to the still lacking consideration of urban-rural linkages of ecosystem services and related measures.

So far, the majority of progress has been achieved through externally-financed research or pilot projects (e.g., the GreenClimaAdapt 2009-2013 project financed by the European Union in Malmö, and ExWoSt project 2009-2013 in Nürnberg and Regensburg financed by the German Federal Ministry for the Environment, Nature Conservation and Nuclear Safety). In both countries, implicit measures (which have adaptation co-benefits) are often linked to an increasing commitment to environmental planning (which can be linked to overall [nonspecific] EPI) and a push for more-integrated flood risk management. While work on flood management remains dominated by technical (engineering-focused) flood protection measures, current European Union initiatives increasingly support integrated approaches that promote ecosystem-based adaptation (EU 2007; StMUG 2014).

Consistent with earlier work on EPI and adaptation mainstreaming (e.g., Burch 2010; Dannevig et al. 2012; Lenschow 2002; Van den Bergh et al. 2011), the ability of all German and Swedish municipalities to implement mainstreaming was found to be dependent on a range of contextual factors, such as existing legislation, the level of commitment of individual officials and the size of the city and its resources. However, it was also linked to municipalities' prior policy integration/mainstreaming experience (Section 3.1).

In fact, in Germany and Sweden civil servants build on EPI and adjust established mainstreaming structures processes and instruments for ecosystem services or climate change mitigation in order to engage in ecosystem-based adaptation within their 'normal' activities. Ecosystem-based adaptation is consequently most advanced in those municipalities where earlier mainstreaming efforts have been successful. In this context, the previous creation of decentralized structures that promote inter-disciplinary and inter-departmental planning, and the appointment of officials who are responsible for mainstreaming, was identified to be crucial. In contrast, success is limited when ecosystem-based adaptation was not linked to existing planning structures and processes, often a result from externally funded engagement. For instance, in Malmö the municipal climate adaptation strategy was created by the Environment Department as a deliverable for the European Union-funded project GRaBS (Green and Blue Space Adaptation for Urban Areas and Eco Towns), which ended in 2011. Municipal staff report that the plan "[...] was never formally used". ${ }^{10}$

While in theory, ecosystem-based adaptation is framed as a comprehensive approach, rooted in ecosystem services and climate change adaptation research (Chong 2014; Uy and Shaw 2012), current practice in both countries is fragmented, and it is not necessarily

\footnotetext{
$\overline{{ }^{10} \text { In contrast, Munich's currently }}$ developed adaptation strategy evolved from activities for climate change mitigation (e.g., climate assessments), was pushed internally by municipal staff, is now supported through lasting changes in personnel assets, working structures and policy support, and actively involves 7 departments and ca. 60 municipal staff members.
} 
supported by theory. For instance, heat and flood risk policies are compartmentalized (strategy 5), and related (ecosystem-based) activities are developed and implemented independently (strategies 1-2). This is linked to the fact that only flood protection receives highlevel guidance (from core legislative powers and other actors at European, national and regional levels; vertical mainstreaming [Fig. 2]). As for heat and other climate-related risks, mainstreaming is mainly associated with the work of departments that encourage or coordinate adaptation, but have little authority (horizontal mainstreaming [Fig. 2]; cf. Jacob and Volkery 2004; Nunan et al. 2012).

In addition, in both Germany and Sweden mainstreaming has, so far, only resulted in a limited extension of municipalities' networks with other stakeholders (strategy 6). This creates challenges for effective and efficient adaptation since governance and problem scales (e.g. municipal borders, climate hazards and ecosystems) generally do not match and, thus, require cooperation with other planning and decision-making levels (Dewulf et al. 2015). Cooperation with neighbouring municipalities and regional bodies tends to be confined to flood risk management.

There are, furthermore, very few efforts to collaborate with citizens for the co-creation of local policies and practices (see also Section 3.2), which supports the outcomes of a recent survey of ecosystem-based adaptation (Brink et al. 2016). This contrasts with climate change mitigation, where cooperation and collaborative arrangements between local authorities and residents are seen as vital to achieving sustainable change. The basic tenet here is that citizens (either as individuals or as members of groups) can, and should, play an important part in related efforts (cf. Gausset and Hoff 2013; Hoff and Gausset 2015). This discrepancy between climate change mitigation and adaptation illustrates a generally low consideration of the adaptationmitigation interface, even when related processes and structures are linked (see Section 3.1).

\section{Discussion and conclusions}

This study provides important insights into potential pathways for mainstreaming ecosystembased adaptation in municipal planning to foster comprehensive climate policy integration and sustainable transformation. The results show that municipalities that have already successfully integrated other cross-cutting issues are more likely to make progress in adaptation mainstreaming, which stands in contrast to previous studies (Agrawala and Van Aalst 2008; Kok and de Coninck 2007).

The results provide empirical evidence that, while the entry points for ecosystem-based adaptation mainstreaming are diverse, progress is driven by the commitment of municipalities to cross-cutting issues other than adaptation. Municipalities' involvement in environmental planning and EPI (in Germany and Sweden), their support for the ecosystem services concept (in Sweden) or climate change mitigation (in Germany), provides the necessary structures, processes and instruments and paves the way for progress in adaptation mainstreaming. Ecosystem-based adaptation is thus more advanced in those municipalities where previous mainstreaming efforts linked to EPI have been successful.

Environmental policy integration and planning can thus be seen as the precursor to current progress in the mainstreaming of ecosystem-based adaptation. Both Sweden and Germany are considered forerunners of EPI in Europe (Hertin and Berkhout 2001; Jordan and Lenschow 2000; Lenschow 2002; Müller 2002; Persson et al. 2015). Beginning in the 1980s, many municipalities have improved their organisational structures and planning policies in ways that 
support environmental mainstreaming. This, in turn, has enhanced organisational structures, processes and instruments that support the integration of emerging, cross-cutting issues.

Nevertheless, the results also revealed fragmented climate policy integration, i.e., the disconnection of mainstreaming processes focused on climate change mitigation and adaptation, and a general mitigation-adaptation dichotomy ${ }^{11}$, which can hamper sustainable transformation. There is increasing consensus that sustainable municipal development requires integrated planning practice and policies that include both climate change mitigation and adaptation considerations (Swart and Raes 2007; IPCC 2014). This mitigation-adaptation interface has high priority in research and innovation in addressing climate change in cities (EC 2015).

In Germany, further promotion of the (so far rather spurned) ecosystem services concept by rephrasing it in line with the concept of nature-based solutions might increase its acceptance in municipal planning and help to foster mainstreaming. Research on the benefits of ecosystem-based adaptation and its mainstreaming at local level should be extended, as in both countries externally-funded projects and studies have promoted its adoption in practice.

Regardless of the actual triggers and entry points, this study also highlights the fact that different mainstreaming strategies can complement and reinforce each other. A firm commitment to certain activities can, to some extent, compensate for a lack of progress in other areas. Sustainable change will, however, remain elusive as long as our understanding of mainstreaming remains naïve; it is the organisations themselves that need to change, rather than only 'mainstreaming' change in selected on-the-ground measures.

Furthermore, the results show a lack of citizen involvement in ecosystem-based adaptation, as has been found in other European and international contexts (Naumann et al. 2011; Brink et al. 2016). This is unfortunate since local adaptation policies and planning should create conditions that foster autonomous adaptation at the private household level, and provide public adaptation when autonomous adaptation is insufficient or fails to take place (Stern 2007; IPCC 2001). Further research is needed on the potential role of citizen-city collaboration in creating change in local policies and practices.

We conclude that systematic adaptation mainstreaming (which addresses all levels of mainstreaming) is a promising avenue for promoting sustainability transformations, independent of local triggers or entry points, but requires comprehensive climate policy integration to avoid further compartmentalization. We therefore call for more research on the role of inclusive (as opposed to fragmented) climate policy integration and related impact assessments to advance sustainable planning and transformation.

Acknowledgments This study was carried out as part of the "Sustainable Urban Transformation for Climate Change Adaptation" research project funded by the Swedish Research Council (FORMAS). We especially thank the municipalities that participated in this study. Thanks also go to Ebba Brink, Henner Busch, Sanna Ståhlhammar, Thomas Beery, Christopher Lüderitz and Adelina Osmani for their input in this or previous studies.

Open Access This article is distributed under the terms of the Creative Commons Attribution 4.0 International License (http://creativecommons.org/licenses/by/4.0/), which permits unrestricted use, distribution, and reproduction in any medium, provided you give appropriate credit to the original author(s) and the source, provide a link to the Creative Commons license, and indicate if changes were made.

\footnotetext{
${ }^{11}$ Such dichotomy has also been identified in other planning-related studies (e.g., Biesbroek et al. 2009).
} 


\section{References}

Agrawala S, Van Aalst M (2008) Adapting development cooperation to adapt to climate change. Clim Pol 8:183-193

Albert C, von Haaren C, Galler C (2012) Ökosystemdienstleistungen: Alter Wein in neuen Schläuchen oder ein Impuls für die Landschaftsplanung? Naturschutz und Landschaftsplanung 44:142-148

Albert C, Aronson J, Fürst C, Opdam P (2014) Integrating ecosystem services in landscape planning. Landsc Ecol 29:1277-1285

Andersson L, Bohman A, van Well L, Jonsson A, Persson G, och Farelius J (2015) Underlag till kontrollstation 2015 för anpassning till ett förändrat klimat. SMHI Klimatologi Nr 12, SMHI, Norrköping, Sverige

Andrade A, Córdoba R, Dave R, Girot P, Herrera-F B, Munroe R, Oglethorpe J, Paaby P, Pramova E, Watson J, Vergara W (2011) Draft principles and guidelines for integrating ecosystem-based approaches to adaptation in project and policy design. Policy brief, CATIE no. 46

Bateson G (1979) Mind and nature: a necessary unity - advances in systems theory, complexity, and the human sciences. Hampton Press, New Jersey, USA

Benson C, Twigg J, Rossetto T (2007) Tools for mainstreaming disaster risk reduction: guidance notes for development organizations. ProVention Consortium, Geneva, Switzerland

Berkhout F, Bouwer LM, Bayer J, Bouzid M, Cabeza M, Hanger S, Hof A, Hunter P, Meller L, Patt A, Pfluger B, Rayner T, Reichardt K, van Teeffelen A (2015) European policy responses to climate change: progress on mainstreaming emissions reduction and adaptation. Reg Environ Chang 15(6): 949-959

BfN (2012) Ökosystembasierte Ansätze zur Klimaanpassung und zum Klimaschutz im deutschsprachigen Raum. Project of the Federal Office for Nature Conservation (BfN), Bonn, Germany

Biesbroek GR, Swart RJ, van der Knaap WGM (2009) The mitigation-adaptation dichotomy and the role of spatial planning. Habitat Int 33(3):230-237

Brink E, Aalders T, Hoffmann A, von Schuckmann L, Riewerts B, Rau AL, Negrut L, Feller RL, Meyer M, von Wehrden H, Abson D, Wamsler C (2016) Cascades of green: a review of ecosystem-based adaptation in urban areas. Glob Environ Chang 36:111-123

Burch S (2010) Transforming barriers into enablers of action on climate change: insights from three municipal case studies in British Columbia, Canada. Glob Environ Chang 20:287-297

Casado-Asenio J, Steurer R (2012) CLIP-IN: climate policy integration in federal states: adaptation, mitigation and sustainable development in Austria, Germany and Switzerland. Analytical framework. Institute for Forest, Environmental, and Natural Resource Policy, Berlin, Germany

CBD (2009) Connecting biodiversity and climate change mitigation and adaptation: report of the second ad hoc technical expert group on biodiversity and climate change (AHTEG). CBD Technical Series No. 41, Montreal, Canada

Chong J (2014) Ecosystem-based approaches to climate change adaptation: progress and challenges. Int Environ Agreements Polit Law Econ 14:391-405

Collier U (1994) Energy and environment in the European Union. Aldershot-Avebury, UK

Collier U (1997) Sustainability, subsidiarity and deregulation: new directions in EU environmental policy. Environ Pol 6(2):1-23

Colls A, Ash N, Ikkala N (2009) Ecosystem-based Adaptation: a natural response to climate change. IUCN, Gland, Switzerland, 16 pp

Corbin J, Strauss A (1990) Grounded theory research: procedures, canons, and evaluative criteria. Qual Sociol 13(1):3-21

Daily GC, Matson P (2009) Ecosystem services: from theory to implementation. Proc Natl Acad Sci U S A 105: 9455-9456

Daily GC, Polasky S, Goldstein J, Kareiva PM, Mooney HA, Pejchar L, Ricketts TH, Salzman J, Shallenberger R (2009) Ecosystem services in decision making: time to deliver. Front Ecol Environ 7:21-28

Dalal-Clayton B, Bass S (2009) The challenges of environmental mainstreaming: experiences of integrating environment into development institutions and decisions. Environmental Governance No. 3. IIED, London, UK

Dannevig H, Rauken T, Hovelsrud G (2012) Implementing adaptation to climate change at the local level. Local Environ 17:597-611

DC (2014) The global green economy index (GGEI) 2014. 4th Edition. Dual Citizen (DC) LLC, Washington, New York

Dewulf A, Meijerink S, Runhaar H (2015) Editorial for the special issue on the governance of adaptation to climate change as a multi-level, multi-sector and multi-actor challenge: a European comparative perspective. J Water Clim Chang 6(1):1-8

DWD (2014) Deutscher Klimaatlas. Deutscher Wetterdienst (DWD), Geschäftsbereich des Bundesministeriums für Verkehr und Digitale Infrastruktur (BMVI), Offenbach, Germany 
EC (European Commission) (2015) Towards an EU research and innovation policy agenda for nature-based solutions and re-naturing cities. Final report of the Horizon 2020 expert group on 'nature-based solutions and re-naturating cities'. Directorate-General for Research and Innovation, EC, Luxembourg

EEA (2012) Urban adaptation to climate change in Europe: Challenges and opportunities for cities together with supportive national and European policies. European Environmental Agency (EEA). Technical report No 2/2012, $143 \mathrm{pp}$

Eggenberger M, Partidario M (2000) Development of a framework to assist the integration of environmental, social and economic issues in spatial planning. Impact Assess Proj Apprais 18(3):201-207

EU (European Union) (2007) Directive 2007/60/EC of the European Parliament and of the Council of 23 October 2007 on the assessment and management of flood risks. Off. J. Eur. Union L288/27

ICLEI Europe (2015) Local authorities self-assessment of Local Agenda 21. Free, online self-assessment tool for local governments to evaluate processes and progress towards sustainable development. ICLEI

Gaffin SR, Rosenzweig C, Kong A (2012) Adapting to climate change through urban green infrastructure. Nat Clim Chang 2(10):704-704

Gausset Q, Hoff, J (eds) (2013) Citizen driven environmental action. J Transdiscipl Environ Stud 12(1):1-3

Geneletti D, Zardo L (2016) Ecosystem-based adaptation in cities: an analysis of European urban climate adaptation plans. Land Use Policy 50:38-47

Glaser BG, Strauss AL (1967) The discovery of grounded theory. Aldine de Gruyter, New York, New York, USA

Glaser BG, Strauss AL (1980) Time for dying (first published in 1968). Aldine de Gruyter, New York

Hertin J, Berkhout, F (2001) Ecological modernisation and EU environmental policy integration. SPRU Electronic Working Paper Series paper no. 72, University of Sussex, Brighton, UK

Hoff J, Gausset Q (eds) (2015) Community governance and citizen driven initiatives in climate change mitigation. Routledge/Earthscan, London, UK

Holden S (2004) Mainstreaming HIV/AIDS in development and humanitarian programmers. Oxfam GB, Oxford

SMHI (Sveriges Meteorologiska och Hydrologiska Institut) (2011) Klimatanalys för Skåne län. Norrköping

IPCC (2001) Third assessment report (TAR). Cambridge University Press, Cambridge, UK

IPCC (2012) Managing the risks of extreme events and disasters to advance climate change adaptation. SREX report. Cambridge University Press, Cambridge, UK

IPCC (Intergovernmental Panel on Climate Change) (2014) Climate change 2014: impacts, adaptation, and vulnerability. Cambridge University Press, Cambridge, UK

Jacob K, Volkery A (2004) Institutions and instruments for government self-regulation: environmental policy integration in a cross-country perspective. J Comp Policy Anal Res Pract 6:291-309

Johansson B, Mobjörk M (2009) Climate adaptation in Sweden: organization and experiences. FOI, Stockholm, Sweden

Jones HP, Hole DG, Zavaleta ES (2012) Harnessing nature to help people adapt to climate change. Nat Clim Chang 2:504-509

Jordan A, Lenschow A (2000) Greening the European Union: what can be learned from the 'leaders' of EU environmental policy. Eur Environ 10(3):109-120

Jordan A, Lenschow A (2010) Environmental policy integration: a state of the art review. Environ Policy Gov 20: $147-158$

Jost GF, Jacob K (2004) The climate change policy network in Germany. Eur Environ 14:1-15

Kok MTJ, de Coninck HC (2007) Widening the scope of policies to address climate change: directions for mainstreaming. Environ Sci Pol 10:587-599

La Trobe S, Davis I (2005) Mainstreaming disaster risk reduction: a tool for development Organizations. Tearfund, UK

Lafferty W (2002) Adapting government practice to the goals of sustainable development. Improving governance for sustainable development. OECD Seminar 22-23 November 2001, OECD, Paris, France

Länsstyrelsen i Skåne län (2014) Biologisk mångfald i de skånska kommunernas planeringsunderlag och verksamheter. Malmö, Länsstyrelsen i Skåne län

Layder D (2005) Sociological practice: linking theory and social research (first published in 1998). Sage, London

Lenschow A (1999) The greening of the EU: the common agricultural policy and the structural funds. Environ Plan C 17:91-108

Lenschow A (ed) (2002) Environmental policy integration: greening sectorial policies in Europe. Earthscan, London, UK

Mazey S (2002) Gender mainstreaming strategies in the EU. Fem Leg Stud 10:227-240

Ministry of the Environment (2013) Making the value of ecosystem services visible: proposals to enhance wellbeing through biodiversity and ecosystem services. Stockholm, Sweden

Mullally G, Dunphy, NP (2015) State of play review of environmental policy integration literature. Research Series Paper No. 7. National Economic and Social Council, Dublin, Ireland 
Müller E (2002) Environmental policy integration as a political principle: the German case and the implications of European policy. In: Lenschow A (ed) Environmental policy integration. Earthscan, London, UK, pp 59-79

Munang R, Thiaw I, Alverson K, Mumba M, Liu J, Rivington M (2013) Climate change and ecosystem-based adaptation: a new pragmatic approach to buffering climate change impacts. Curr Opin Environ Sustain 5(1):67-71

Naumann S, Anzaldua G, Berry P, Burch S, Davis M, Frelih- Larsen A, Gerdes H, Sanders M (2011) Assessment of the potential of ecosystem-based approaches to climate change adaptation and mitigation in Europe. Final report to the European Commission, DG Environment. Ecologic institute and Environmental Change Institute, Oxford University Centre for the Environment, UK

Naumann S, Kaphengst T, McFarland K, Stadler J (2014) Nature-based approaches for climate change mitigation and adaptation. The challenges of climate change - partnering with nature. German Federal Agency for Nature Conservation (BfN), Bonn, Germany

Nunan F, Campbell A, Foster E (2012) Environmental mainstreaming: the organizational challenges of policy integration. Public Adm Dev 32(3):262-277

Ojea E (2015) Challenges for mainstreaming ecosystem-based adaptation into the international climate agenda. Curr Opin Environ Sustain 14:41-48

Pasquini L, Cowling, R (2014) Opportunities and challenges for mainstreaming ecosystem-based adaptation in local government: evidence from the Western Cape, South Africa. Environment, Development and Sustainability $1-20$

Pelling M, O’Brien K, Matyas D (2014) Adaptation and transformation. Clim Chang. Online first

Persson (2004) Environmental policy integration: an introduction. PINTS - Policy Integration for Sustainability, background paper, Stockholm Environment Institute (SEI), Sweden

Persson A, Eckerberg K, Nilsson M (2015) Institutionalization or wither away: 25 years of environmental policy integration in Swedish energy and agricultural policy. Environ Plan C doi:10.1177/0263774X15614726

Picciotto R (2002) The logic of mainstreaming: a development evaluation perspective. Evaluation 8:322-339

Revi A, Satterthwaite D, Aragón-Durand F, Corfee-Morlot J, Kiunsi R, Pelling M, Roberts D, Solecki W, Pahwa Gajjar S, Sverdlik A (2014) Towards transformative adaptation in cities: the IPCC's fifth assessment. Environ Urban 26:11-21

Sitas N, Prozesky H, Esler K, Reyers B (2014) Exploring the gap between ecosystem service research and management in development planning. Sustainability 6:3802-3824

SOU (2007) Sweden facing climate change - threats and opportunities. Final report from the Swedish commission on climate and vulnerability. Stockholm, Sweden

SOU (2013) Making the value of ecosystem services visible. Proposals to enhance well-being through biodiversity and ecosystem services. Swedish Government Enquiries. SOU 2013:68, Stockholm

Stern N (2007) Policy responses for adaptation. Stern review on the economics of climate change. HM Treasury, London, UK

StMUG (Bayerisches Staatsministerium für Umwelt und Gesundheit) (2014) Handlungsanleitung zur Erarbeitung von Hochwasserrisikomanagement-Plänen in Bayern. StMUG, Munich, Germany

Strauss AL, Corbin J (1998) Basics of qualitative research. Techniques and procedures for developing grounded theory, 2nd edn. Sage, Thousand Oaks, CA

Swart R, Raes F (2007) Making integration of adaptation and mitigation work: mainstreaming into sustainable development policies? Clim Pol 7:288-303

Turnpenny J, Russel D, Jordan A (2014) The challenge of embedding an ecosystem services approach: patterns of knowledge utilisation in public policy appraisal. Environ Plan C Gov Policy 32:247-262

Uittenbroek CJ, Janssen-Jansen LB, Runhaar H (2013) Mainstreaming climate adaptation into urban planning: overcoming barriers, seizing opportunities and evaluating the results in two Dutch case studies. Reg Environ Chang 13(2):399-411. doi:10.1007/s10113-012-0348-8

UNISDR (2005) Hyogo framework for action 2005-2015: building resilience of nations and communities to disasters. World conference on disaster reduction, Kobe, Hyogo, Japan

United Nations (1987) Our common future - Brundtland report. Oxford University Press, Oxford, UK

Uy N, Shaw R (eds) (2012) Ecosystem-based adaptation. Emerald Group Publishing Ltd, Bradford, UK

Van Asselt H, Rayner T, Persson Å (2015) Climate policy integration, in Bäckstrand K, Lövbrand E. (eds) Research handbook on climate governance. Edward Elgar, Cheltenham, UK, chapter 34 24:388-399

Van den Bergh JCJM, Truffer B, Kallis G (2011) Environmental innovation and societal transitions: introduction and overview. Environ Innov Soc Transit 1:1-23

Vignola R, Locatelli B, Martinez C, Imbach P (2009) Ecosystem-based adaptation to climate change: what role for policy-makers, society and scientists? Mitig Adapt Strateg Glob Chang 14:691-696

von Bertalanffy L (1950) An outline of general systems theory. Br J Philos Sci 1(2):134-165

Wamsler C (2014) Cities, disaster risk and adaptation. Routledge, London, UK 
Wamsler C (2015a) Mainstreaming ecosystem-based adaptation: transformation toward sustainability in urban governance and planning. Ecol Soc 20(2):30

Wamsler C (2015b) Guideline for integrating climate change adaptation into municipal planning and governance. Working Paper 31. Disaster Studies and Management Working Paper Series, University College London (UCL) Hazard Centre, London

Wamsler C, Brink E (2014) Adaptive capacity: from coping to sustainable transformation. In: Eriksen S, Inderberg T, O’Brien K, Sygna L (eds) Climate change adaptation and development: transforming paradigms and practices. Routledge, London, UK, pp 54-82

Wamsler C, Luederitz C, Brink E (2014) Local levers for change: mainstreaming ecosystem-based adaptation into municipal planning to foster sustainability transitions. Glob Environ Chang 29:189-201

Wamsler C, Niven L, Beery T, Bramryd T, Ekelund N, Jönsson I, Osmani A, Palo T, Stålhammar S (2016) Operationalizing ecosystem-based adaptation: harnessing ecosystem services to buffer communities against climate change'. Ecol Soc 21(1):31

Westley F, Olsson P, Folke C, Homer-Dixon T, Vredenburg H, Loorbach D, Thompson J, Nilsson M, Lambin E, Sendzimir J, Banerjee B, Galaz V, Leeuw S (2011) Tipping toward sustainability: emerging pathways of transformation. Ambio 40:762-780

Wilkinson C, Saarne T, Peterson GD, Colding J (2013) Strategic spatial planning and the ecosystem services concept - an historical exploration. Ecol Soc 18(1):37

Wu J (2014) Urban ecology and sustainability: the state-of-the science and future directions. Landsc Urban Plan 125:209-221 